\title{
ПИТАННЯ ГРАМАТИКИ
}

http://dx.doi.org/10.18524/2307-4558.2018.30.154331

УДК 811.111’366.582-116/.133

КОСОВЕЦБ Маргарита Валеріївна, магістрант кафедри англійської мови Одеського національного університету імени I. I. Мечникова, Французький бульвар, 24/26, м. Одеса, 65058, Україна; тел.: +38 063 4674101; e-mail: kosovets13@gmail.com; ORCID ID: 0000-0003-1124-6025.

\section{ТЕОРЕТИЧНІ АСПЕКТИ ПРОСТОГО МИНУЛОГО ЧАСУ В СУЧАСНІЙ АНГЛІЙСЬКІЙ MOBI}

\begin{abstract}
Анотація. У статті висвітлено проблему теоретичного трактування простого минулого часу в англійській мові. Мета - висвітлити теоретичні аспекти, пов'язані з простим минулим та показати їх суперечливість. Об'єкт дослідження: категорія часу в сучасній англійської мові, зокрема така видочасова форма як простий минулий час. Предметом дослідження є простий минулий час та особливості його вживання. У процесі аналізу фактичного матеріалу було використано метод дистрибуції як спеціальний метод лінгвістичного аналізу, що дає змогу системно вивчати формальні особливості досліджуваного явища у середовищі його безпосереднього оточення. У процесі обробки фактичного матеріалу дистрибутивний метод застосовувався в поєднанні з методом контекстуального аналізу з метою визначення граматичного значення досліджуваної видо-часової форми. У результаті проведеної роботи висвітлено та проілюстровано прикладами одну з найважливіших проблем нашого дослідження, а саме - варіативність граматичного значення простого минулого. Виявлено, що досі немає єдиної назви для простого минулого часу, а також єдиного граматичного значення простого минулого. Висновком дослідження $\mathrm{\epsilon}$ підтвердження факту, що попри чисельні дослідження видо-часових форм простого минулого часу англійської мови проблема невизначеності цієї граматичної категорії у її трактуванні залишається невирішеною.

Ключові слова: видо-часова форма дієслова, минулий неозначений час, граматичне значення, англійська мова, передування.
\end{abstract}

Постановка дослідницької проблеми. Як свідчать проаналізовані нами теоретичні джерела, проблема граматичного часу в англійській мові є до цього часу до кінця не дослідженою. На цей факт вказують такі авторитетні лінгвісти: У. Дайвер, Р. Деклерк, Е. Даль, Б. Комрі, О. І. Смирницький, O. Єсперсен, деякі інші. До цього часу, зокрема, не вирішені проблеми граматичного значення таких видо-часових форм, як теперішній перфектний та простий минулий. Вони до цього часу залишаються "яблуком розбрату» серед лінгвістів. Отже, вивчення зазначеної проблеми є актуальним у сучасній лінгвістиці.

Зв’язок проблеми з попередніми дослідженнями. В. Дайвер у 1969 році писав: «Один з курйозних аспектів сучасного лінгвістичного аналізу полягає в тому, що англійська мова, хоча піддавалася і піддається широкому та інтенсивному дослідженню, містить ряд царин, стосовно яких продовжують існувати широкі розбіжності. Ніде це так не очевидно, як в англійському дієслові» [16, с. 141]. Не залишилася ця проблема й поза увагою радянських і вітчизняних англістів. Її досліджували Г. Н. Воронцова [3, с. 13-14], І. П. Іванова [5, с. 107], А. К. Корсаков [18, с. 5], О. І. Смирницький $[11$, с. 294$]$, багато інших лінгвістів. Незважаючи на це, багато аспектів залишаються так само невирішеними і потребують подальшого дослідження.

Формулювання дослідницьких завдань. Метою цієї статті є висвітлення теоретичних аспектів, пов'язаних із простим минулим часом англійської мови та показати їхню суперечливість. Об'єктом дослідження ми обрали категорію часу сучасної англійської мови, зокрема видо-часову форму простого минулого часу. Предметом дослідження виявилися мовленнєві особливості вживання цієї граматичної категорії в англійській мові. У процесі аналізу фактичного матеріалу було використано метод дистрибуції як спеціальний метод лінгвістичного аналізу, що дає змогу системно вивчати формальні особ̆ливості досліджуваного явища у середовищі його безпосереднього оточення. Під час обробки фактичного матеріалу дистрибутивний метод застосовувався в поєднанні з методом контекстуального аналізу з метою визначення граматичного значення досліджуваної видо-часової форми.

Виклад основного матеріалу. Найперше, що впадає у вічі, це те, що до цього часу вчені остаточно не визначились, щодо назви цієї часової форми. Як показує навіть поверхневий аналіз, єдиної назви для цієї форми досі не існує. У теоретичних і практичних граматиках для визначення простого минулого часу використовують такі назви: past indefinite (минуле невизначене), past simple (про- 
сте минуле), past static (минуле статичне), або просто past tense (минулий час). Деякі граматисти використовують дві назви одразу: past indefinite i past simple tense, наприклад, Т. Г. Камянова, Т. Ю. Дроздова [4; 7]. Вітчизняні граматисти віддають перевагу назві past indefinite (минуле невизначене), тоді як зарубіжні — past simple (просте минуле).

Окрім розбіжностей у назві, існують також різні підходи у визначенні граматичного значення минулого статичного. Вивчивши теорію питання, ми встановили, що більшість граматистів дає одне граматичне значення статичного минулого, утім, в окремих джерелах пропонують декілька рівноцінних визначень або ж одне основне, яке потім деталізують.

Проаналізуємо спочатку точку зору тих лінгвістів, які надають одне основне значення, що потім деталізується. Це Л. В. Банкевич [1, с. 308], К. Н. Качалова [6, с. 120], В. Л. Каушанська [8, с. 102], Н. А. Кобріна [9, с. 47], І. П. Крилова [10, с. 32], Майкл Свон [23, с. 394], Mark Foley (Марк Фолій) [17, с. 98] та ін.

Почнемо з аналізу базових визначеннь, яке дають вищезгадані граматисти. Зіставивши їх, ми виявили низку відмінностей. Перш за все - це визначальне, ключове, слово. Оскільки часові форми вказують на граматизовані часові відношення, цим ключовим словом у нашому випадку є минуле, а точніше - трактування поняття (минулого) граматистами. Більшість граматистів, згідно 3 результатами нашого аналізу, вказують на часові відношення, визначаючи минуле статичне як часову форму, що слугує для вираження специфіки буття субстанції саме в минулому, підкреслюючи непов’язаність цієї форми з моментом мовлення. І. П. Крилова, зокрема, вказує: „Просте невизначене, зазвичай, використовується для вираження дії в минулому» ("The Past Indefinite is commonly used to express a past action") [10, с. 20]. Аналогічне трактування простого минулого зустрічаємо у К. Н. Качалової. На її думку, “Past Indefinite служить для вираження дії, яка відбулась або відбувалася в минулому” [6, с. 120].

Підкреслюючи несумісність дії, позначеної простим невизначеним, з теперішнім часом, В. Л. Каушанська вказує: “Дію (відрізано» від теперішнього моменту» (“The action is cut off from the present») [8, с. 102]. Л. В. Банкевич пише: “Характерною особливістю минулого невизначеного є те, що дії або стан, які передає ця граматична часова форма, мисляться як непов'язані з моментом мовлення, та які не мають наслідків у теперішньому" [1, с. 308].

Деякі граматисти надають визначенню минулого статичного видового відтінку, а саме - «завершеності дії) або ж (повторюваності дії). Прикладом цього може слугувати визначення Марка Фолійя, який додає до значення минулого ще й видове значення завершеності: «Ми вживаємо простий минулий, - пише він, - у випадку завершених дій у минулому» ("We use past simple for completed actions in the past») [17, с. 98]. До цієї ж точки зору приєднується й В. Л. Каушанська, яка вказує на завершеність періоду, протягом якого дія відбувалась: (минулий невизначений вказує на дію у межах часу, який вже закінчився» (“The Past Indefinite denotes an action performed within a period of time which is already over») [8, с. 102].

На відміну від попередніх граматистів, які видовим значенням минулого невизначеного вважають завершеність дії, Л. В. Банкевич на чільне місце у своєму визначенні ставить такі видові значення, як (регулярну (постійну) повторюваність дії у минулому», застерігаючи про можливість вираження минулим невизначеним поодиноких дій. “Форма Past Indefinite, - пише він, - позначає постійні, регулярно повторювані дії в минулому; або ця форма може також виражати поодинокі дії (або стан) у минуломул $[1$, с. 308].

Більш опукло виявляються суперечності між граматистами, якщо детально проаналізувати й зіставити визначення, як мінімум, двох граматистів. Для прикладу, візьмемо визначення Н. O. Кобріної та Майкла Свона. Перше, що впадає у вічі, це те, що Н. О. Кобріна підкреслює, що простий невизначений час вказує на факти в минулому, тоді як Майкл Свон узагалі не вказує на будь-які часові відношення. Так, Н. О. Кобріна пише, що (минулий невизначений вживають на позначення простих фоктів у минулому» (“The Past Indefinite is used to state simple facts in the past») [9, с. 47]. Майкл Свон вважає, що (просте минуле використовують для вираження багатьох різновидів подій» ( (We use the Simple Past form any kinds of events») [23, с. 47]. Концепції Н. О. Кобріної та М. Свона відрізняються від точок зору більшості граматистів цієї групи ще й тим, що в той час, коли більшість послуговується словом (дія) для зображення буттєвого аспекту процесів об'єктивного світу, ці вчені вживають слова “фокти» та (події), відповідно, що добре видно із наведених вище цитат. Окрім цього, в обох граматистів ужито прикметник (простий) "simple», але в різних значеннях. Н. О. Кобріна - у самому тексті визначення, а М. Свон використовує "simple» у назві самої граматичної форми (Н. О. Кобріна ж віддає перевагу назві Past Indefinite) [9, с. 47].

Розглянемо, як саме відбувається деталізація в ознакових підпунктах щойно проаналізованих визначень: що в них є спільного, а що відмінного.

Перша ознака зводиться до того, що обидва граматисти вказують на таку особливість минулого невизначеного, як здатність позначати звичнi, або ж повторювані прочеси (специфочне буття субстанції) у минулому. Однак для Н. О. Кобріної - це (звичні дії» ((habitual actions in the past») [9, c. 47], а для М. Свона - повторювані події („repeated events») [23, c. 394]. Як бачимо, Н. O. Кобріна вживає поняття (фокти» та (дії») як синоніми, М. Свон же дотримується терміну (події». Отже, що 
саме визначає простий невизначений час у цих визначеннях:((факти,) (дії) чи (події)) - i чи $\mathrm{\epsilon}$ вони (звичними» чи (повторюваними) - абсолютно незрозуміло.

Розглянемо наступні ознаки, запропоновані Н. О. Кобріною та М. Своном для визначення минулого невизначеного. Точки зору граматистів щодо наступних ознак, як і попередніх, теж різняться. Це виявляється, передусім, у тому, що (видові властивості) минулого невизначеного кардинально різняться. Окрім цього, граматисти вдаються до різних визначальних слів. Відзначаючи, що минулий невизначений позначає повторювані процеси в минулому, Н. О. Кобріна відзначає також здатність цієї форми виражати як (послідовність дій» у минулому (“a succession of past actions») [9, с. 47] та дії у прогресі в певний момент минулого (“actions in progress at a certain moment in the past») [9, c. 47]. М. Свон, навпаки, підкреслює здатність використовувати простий минулий для вираження коротких, швидко завершених дій, подій (“short quickly finished actions and happenings») [23, с. 394], а також тривалих ситуацій («longer situations») [23, с. 394]. Як бачимо, для Н. О. Кобріної важливою є саме nослідовність діü, тоді ж як М. Свон наголошує на таких характеристиках (дій» та (подій», як швиджість протікання та завершеність. Послідовними чи непослідовними є ці дії та події, він не вказує, як не вказує й того, повторювані вони чи одноразові. Обидва граматисти вказують також на здатність простого минулого виражати й інші за характером дії в минулому. Для Н. О. Кобріної це дія у розвитку, однак тривала вона чи коротка за часом протікання, незрозуміло, тоді ж як М. Свон підкреслює здатність простого минулого виражати саме тривалі (ситуації) в минулому. Ситуація щодо аналізованих визначень ускладняється тим, що обидва граматисти мають різне бачення того, що саме виражає дієслово як таке. Для Н. О. Кобріною це виключно дї̈, тоді ж як для М. Свона це діï, подіï та, зрештою, ситуаиї.

Таким чином, зосередивши нашу увагу на визначеннях двох граматистів, ми ще раз можемо переконатися, що науковці не мають єдиної думки щодо трактування англійського минулого невизначеного.

Далі перейдемо до аналізу точок зору дослідників, які дають одне граматичне значення минулому статичному. До цієї групи ми відносимо точки зору І. Алексєєвої [12, с. 88], Г. О. Васильцова [2, с. 31], І. П. Іванова [5, с. 44], Т. Г. Камянова [7, с. 289], А. К. Корсаков [18, с. 66] та ін.

Загалом, минулий невизначений визначають як категорію, що позначає дію, яку було здійснено раніше моменту мовлення, тобто не пов'язану з моментом мовлення. Однак, як показує аналіз, існує низка розбіжностей, на яких ми зупинимося нижче.

Відправним пунктом для аналізу буде ключове слово (минуле», а точніше — трактування поняття (минулого) граматистами.

Так, зокрема, Т. Г. Камянова визначає минуле статичне як завершену дію, яка відбулася до момента мовлення і з ним не пов'язана [7, с. 289]. Аналогічної точки зору дотримується І. П. Іванова, яка пише, що (минулий час основного (простого) розряду передає дію, що відбувалася у відрізок часу, який закінчився раніше моменту мовлення) [5, с. 44]. (За формою минулого основного розряду, - доповнює автор, - настільки міцно закріпилася фоннція передачі оповіді, що саме використання минулого основного є показником того, що дія відбувається в період, що закінчився до моменту мовлення» [5, с. 45]. Обидві дослідниці підкреслюють видовий (аспектуальний) відтінок значення минулого невизначеного, а саме завершеність дії.

Згідно з точкою зору А. К. Корсакова, (минулий статичний вживається тоді, коли мовець асоціює вербальні процеси з певними обставинами у минулому» (“The Past Static issued when the speaker associates verbal processes with particular circumstances in the past, when he reproduces the past itself») [18, с. 66]. Як бачимо, на відміну від попередніх граматистів, аспект не відіграє жодної ролі у вживанні цієї видо-часової форми.

Дещо іншої думки у визначенні простого невизначеного дотримуються І. Алексєєва і Г. О. Васильцова. Вони визначають цю часову форму як передування шодо теперішнього моменту. Так, Г. О. Васильцова вказує, що (минулий час розміщує процес (на лінії часу) попередньо до теперішнього моменту» (“The past tense locates the process prior to the present moment») [2, с. 31]. Tакої ж думки дотримується й І. Алексєєва, яка теж, як і Г. О. Васильцова, пише, що “минулий час просто розміщує аналізовану ситуацію (на лінії часу) попередньо до теперішнього моменту, не вказуючи, втім, чи минулу ситуацію представлено на лінії часу попереднього до теперішнього моменту, чи то як єдиний пункт, чи то як більш розширену в часі або як таку, що може тривати аж до теперішнього моменту» ("The past tense simply locates the situation in question prior to the present moment and says nothing about whether the past situation occupies just as angle point prior to the present, or extended time prior to the present moment, or indeed the whole time up to the present moment...) [12, c. 88].

Висновки. Таким чином, детально проаналізувавши та зіставивши між собою точки зору граматистів, ми можемо зробити наступний висновок. У граматиці минулий статичний час визначають як завершену дію, що відбулася в минулому, до моменту мовлення, і не пов'язана з останнім, або як передування теперішньому моменту. Інтуїтивно відчуваючи близькість понять “минуле» і (передування», дослідники, водночас, не усвідомлюють розбіжностей, що мають місце в цих поняттях, по суті, ототожнюючи їх. 
Отже, ми висвітлили та проілюстрували прикладами одну із найважливіших проблем нашого дослідження, а саме - варіатівність граматичного значення минулого статичного. Наступні проблеми будуть, у подальшому, піддаватися ретельному аналізу та можуть бути розглянуті в нашому наступному дослідженні.

\section{Л $і$ mер а тура}

1. Банкевич Л. В. Практическое пособие по английскому языку. М. : Высш. шк., 1976. 392 с.

2. Васильцова Г. А. Теоретическая грамматика английского языка. Томск : ТПУ, 2008. 116 с.

3. Воронцова Г. Н. Очерки по грамматике английского языка. М. : Изд-во лит. на иностр. языках, 1960. 363 с.

4. Дроздова T. Ю. English grammar : учеб. пособие. 9-е изд. СПб. : Антология, 2005. 400 с.

5. Иванова И. П. Вид и время в современном английском языке. Л. : ЛГУ, 1961. 400 с.

6. Качалова $K$. H. Практическая грамматика английского языка. К. : Методика, 1957. 363 с.

7. Камянова T. Г. English Grammar. Грамматика английского языка : теория и практика. М. : Дом славянской книги, 2015. 1024 с.

8. Каушанская В. Л. и др. Грамматика английского языка :пособие для студентов. 5-е изд., испр. и доп. М. : Айрис-пресс, 2008. 384 с.

9. Кобрина H. А. Грамматика английского языка. СПб. : Союз, 1999. 371 с.

10. Крылова И. П. Грамматика современного английского языка. 9-е изд. М. : 2003.448 с.

11. Смирничкий А. И. Синтаксис английского языка. 2-е изд., испр. М. : УРСС, 2007. 296 с.

12. Alexeyeva I. Theoretical Grammatical Course of Modern English. Vinnytsya : Nova knyha, 2007. 327 p.

13. Cobuild C. English Grammar. L.: Collins publishers, 2011. 465 p.

14. Comrie B. Tense. N. Y. : Cambridge university press, 1985. 138 p.

15. Declerck R. Tense. N. Y.; L. : Routledge, 2015. 416 p.

16. Diver $W$. The system of relevance of the Homeric verb // Acta Linguistica Hafniensia. 1969. No. 12. Issue 1. P. $45-68$.

17. Foley M. My Grammar Lab. L. : Pearson, 2012. 422 p.

18. Korsakov A. K. The Use of Tenses in English. M. :Vyssh. shk., 1978. 223 p.

19. Langacker R. W. Cognitive Grammar. A basic Introduction. N. Y. : Oxford Univ. Press, 2008. 573 p.

20. Longman Grammar of Spoken and Written English Tense. London : Longman, 1999. 1204 p.

21. McGilvray J. A. Tense, reference, \& worldmaking. L. : McGill-Queen's University Press, 1991. 376 p.

22. Morokhovskaya E. J. Fundamentals of theoretical English Grammar. K. : Vysca skola, 1984. 279 p.

23. Swan M. Practical English Usage. OUP, 1997. 658 p.

\section{References}

1. Bankevich, L. V. (1976), Practical manual in English [Prakticheskoe posobie po angliyskomu yazyku], Vyssh. shk., Moscow, 392 p.

2. Vasiltsova, G. A.(2008), Theoretical Grammar of the English language [Teoreticheskaya grammatika angliyskogo yazyka], TPU, Tomsk, $116 \mathrm{p}$.

3. Vorontsova, G. N.(1960), English grammar essays [Ocherki po grammatike angliyskogo yazyka], Foreign Languages Publishing House, Moscow, $363 \mathrm{p}$.

4. Drozdova, T. U.(2005), English Grammar [Grammatika angliyskogo yazyka], Antology, St. Petersburg, 400 p.

5. Ivanova, I. P. (1961), Aspect and Tense in Modern English [Vid i vremya v sovremennom angliyskom yazyke], LGU, Leningrad, $400 \mathrm{p}$.

6. Kachalova, K. N. (2003), Practical English Grammar [Prakticheskaya grammatika angliyskogo yazyka], Metodika, Kiev, $363 \mathrm{p}$.

7. Kamyanova, T. G. (2015), English Grammar [Grammatika angliyskogo yazyka], Dom Slavyanskoy knigi, Moscow, $384 \mathrm{p}$.

8. Kaushanskaya, V. L. (2008), English Grammar [Grammatika angliyskogo yazyka], Airis-press, Moscow, 384 p. 383 p.

, N. A.(1999), English Grammar [Grammatika angliyskogo yazyka], Writers House, St. Petersburg,

10. Krylova, I. P. (2003), Modern English Grammar, 9th ed. [Grammatika sovremennogo angliyskogo yazyka], Moscow, $448 \mathrm{p}$.

11. Smirnitskiy, A. I. (2007), English language Syntax [Sintaksis angliyskogo yazyka], URSS, Moscow, $296 \mathrm{p}$.

12. Alexeyeva, I. (2007), Theoretical Grammatical Course of Modern English, Nova knyha, Vinnytsya, $327 \mathrm{p}$.

13. Cobuild, C. (2011), English Grammar, Collins publishers, London, 465 p.

14. Comrie, B. (1985), Tense. Cambridge university press, N. Y., 138 p.

15. Declerck, R. (2015), Tense, Routledge, N. Y., London, 416 p.

16. Diver, W. (1969), The system of relevance of the Homeric verb, Acta Linguistica Hafniensia, vol. 12, issue 1, pp. $45-68$

17. Foley, M. (2012), My Grammar Lab., Pearson, London, 422 p.

18. Korsakov, A. K. (1978), The Use of Tenses in English, Vyssh. shk., Moscow, 223 p.

19. Langacker, R. W. (2008), Cognitive Grammar. A basic Introduction, Oxford Univ. Press, N. Y., 573 p.

20. Longman (1999), Grammar of Spoken and Written English Tense, Longman, London, 1204 p.

21. McGilvray, J. A. (1991), Tense, reference, \& worldmaking, McGill-Queen's University Press, London, 376 p.

22. Morokhovskaya, E. J. (1984), Fundamentals of theoretical English Grammar, Vyssh. shk., Kiev, 279 p.

23. Swan M. (1997), Practical English Usage, OUP, 658 p. 
КосоВЕЦ Маргарита Валерьевна,

магистрант кафедры грамматики английского языка Одесского национального университета имени И. И. Мечникова, Французский бульвар, 24/26, г. Одесса, 65058, Украина; тел.: +38 063 4674101;

e-mail: kosovets13@gmail.com; ORCID ID: 0000-0003-1124-6025

\section{ТЕОРЕТИЧЕСКИЕ АСПЕКТЫ ПРОСТОГО ПРОШЕДШЕГО ВРЕМЕНИ В СОВРЕМЕННОМ АНГЛИЙСКОМ ЯЗЫКЕ}

Аннотация. Статья посвящена проблеме теоретической трактовки простого прошедшего времени в английском языке. Цель - осветить теоретические аспекты, связанные с простым прошедшим и показать их противоречивость. Объект исследования: категория времени в современном английском языке, в частности, видо-временная форма простого прошедшего времени. Предмет изучения - особенности употребления простого прошедшего времени в английской речи. В процессе анализа фактического материала был использован дистрибутивный метод, дающий возможность системного изучения формальных особенностей исследуемого явления в его непосредственном окружении. При анализе фактического материала с целью установить грамматическое значение исследуемой грамматической категории дистрибутивный анализ использовался в сочетании с методом контекстуального анализа. В результате проведённой работы мы осветили и проиллюстрировали одну из самых важных проблем нашего исследования, а именно - вариативность грамматического значения простого прошедшего времени. В частности, было установлено, что вплоть до настоящего момента нет единого термина для именования простого прошедшего времени и однозначной интерпретации грамматического значения форм этого времени. Выводом нашего исследования является подтверждение факта, что, несмотря на многочисленные исследования грамматической семантики простого прошедшего времени, проблема неопределённости в его трактовке до настоящего времени окончательно не решена.

Ключевые слова: видо-временная форма глагола, прошедшее неопределённое время, грамматическое значение, английский язык, предшествование.

\section{Margaret Va. KOSOVETS,}

master of the English language grammar Department, Odessa I. I. Mechnikov National University, 24/26 Frantsuzskiy blvd., Odessa, 65058, Ukraine; tel.: +38 0634674101 ;

e-mail: kosovets13@gmail.com; ORCID ID: 0000-0003-1124-6025

\section{THEORETICAL ASPECTS OF THE PAST SIMPLE TENSE IN MODERN ENGLISH}

Summary. The article considers the problem of the theoretical interpretation of the past simple tense beginning from the name up to its grammatical meaning. The purpose is to highlight the theoretical aspects connected with the past indefinite tense and to show their contradiction. The object of the study is the category of tense in Modern English, in particular such a tense form as the past simple. The subject is the past simple tense and the peculiarities of its usage. The method of the study is distribution which contributes to the systematic study of the formal peculiarities of the analyzed phenomenon in its proximate surroundings. This method was followed by such a method as contextual analysis which was used to define the grammatical meaning of the analyzed tense form. Our investigation results in indicating the problem of variety in interpretation of the past simple tense. In particular it was defined that up to the present moment there is neither common term for the analyzed tense form nor common grammatical meaning of the past simple tense. The conclusion can be drawn relying on the fact that despite numerous investigations of the past simple tense, the problem of the uncertainty in interpretation of the past simple tense remains unsolved.

Key words: verb aspect and tense, past indefinite, grammatical meaning, the English language, anteriority.

Статтю отримано 22.10.2018 р. 